\title{
Galatheoid squat lobsters (Crustacea: Decapoda: Anomura) from Korean waters
}

\author{
Jung Nyun Kim", Mi Hyang Kim², Jung Hwa Choi ${ }^{3}$ and Yang Jae $\mathrm{Im}^{1}$
}

\begin{abstract}
Ten species of Galatheoidea (squat lobsters), belonging to two families, were collected in the Korean exclusive economic zone: Galathea balssi Miyake and Baba, 1964, Galathea orientalis Stimpson, 1858, Galathea pubescens Stimpson, 1858, and Galathea rubromaculata Miyake and Baba, 1967 belonging to Galatheidae; Bathymunida brevirostris Yokoya, 1933, Cervimunida princeps Benedict, 1902, Munida caesura Macpherson and Baba, 1993, Munida japonica Stimpson, 1858, Munida pherusa Macpherson and Baba, 1993, and Paramunida scabra (Henderson, 1885) belonging to Munididae. The present study comprises the morphological description of these ten species, including drawings and color photographs, a brief review of their regional records, and a key for their identification. Although all species are common in Japanese waters, G. balssi, G. rubromaculata, B. brevirostris, C. princeps, M. caesura, and M. pherusa are new to Korean marine fauna.
\end{abstract}

Keywords: Galatheidae, Munididae, Squat lobster, Korean fauna

\section{Background}

Based on a phylogenetic study, Ahyong et al. (2010) revised the classification of the superfamily Galatheoidea to include four families: Galatheidae, Munididae, Munidopsidae, and Porcellanidae. The former three families, together with the superfamily Chirostyloidea, which includes Chirostylidae, Eumunidae, and Kiwaidae, are known as "squat lobsters," as their abdomen is tucked under the thorax, giving a "crouching or squatting" appearance (Baba et al. 2009). Squat lobsters are distributed worldwide and play an important role in the marine food webs of coastal marine zones. Some species inhabiting the eastern Pacific and eastern Atlantic are of commercial importance (Poore et al. 2011). Although galatheoid squat lobsters comprise 877 species belonging to 45 genera (World Register of Marine Species 2015), in Korean waters, only four species belonging to three genera of two different families have been reported (Kim and Kim 1997): Galathea orientalis Stimpson, 1858 and Galathea pubescens Stimpson, 1858 in Galatheidae; Munida japonica Stimpson, 1858 and Paramunida

\footnotetext{
* Correspondence: crangonk@korea.kr

'West Sea Fisheries Research Institute, National Institute of Fisheries Science, Incheon 22383, South Korea

Full list of author information is available at the end of the article
}

scabra (Henderson, 1885) (as Munida) in Munididae (as Galatheidae).

The present study provides morphological descriptions and illustrations for ten species of squat lobsters (four Galatheidae and six Munididae), collected in the Korean exclusive economic zone during a fisheries resources investigation conducted by the National Institute of Fisheries Science (Korea), from 2003 to 2013. Of these, six species are recorded for the first time in Korean waters: Bathymunida brevirostris Yokoya, 1933, Cervimunida princeps Benedict, 1902, Galathea balssi Miyake and Baba, 1964, Galathea rubromaculata Miyake and Baba, 1967 Munida caesura Macpherson and Baba, 1993, and Munida pherusa Macpherson and Baba, 1993. Eight of the ten Korean species occur in the West Pacific and $B$. brevirostris is endemic to the Korea and Tsushima Straits. Two other species, G. pubescens and Paramunida scabra are widely distributed in the Indo-West Pacific. A key for their identification is also provided.

\section{Methods}

The specimens examined in this study were deposited in the National Institute of Fisheries Science, Korea. Individuals were collected by SCUBA diving for $G$. orientalis and bottom otter trawls (mesh size at the cod end $=0.98 \times 0.98 \mathrm{~mm}$ ), operating during daytime for 30 - 
$60 \mathrm{~min}$ at 3.4 knots, on average for the other species. All samples were frozen on board shortly after capture and maintained at $-80{ }^{\circ} \mathrm{C}$ until their morphological identification in the laboratory. Specimens were photographed before their identification, and then preserved in 70$90 \%$ ethyl alcohol.

Carapace length $(\mathrm{CL})$ was determined measuring the distance from the posterior margin of the orbit to the posterior mid-dorsal margin of the carapace, and used to indicate specimen size. The terminology used in descriptions mainly follows that of Baba et al. (2009). Species are arranged in alphabetical order.

\section{Results and discussion}

\section{Superfamily Galatheoidea Samouelle, 1819}

(Korean name: Sae-u-but-i-sang-gwa)

Family Galatheidae Samouelle, 1819

(Korean name: Sae-u-but-i-gwa)

Genus Galathea Fabricius, 1793

(Korean name: Sae-u-but-i-sok)

Galathea balssi Miyake and Baba, 1964

(New Korean name: Bal-seu-sae-u-but-i)

(Figs. 1 and 11a)

Galathea australiensis Balss, 1913: 13, Fig. 13 (not G. australiensis Stimpson, 1858).

Galathea balssi Miyake and Baba, 1964: 205, Figs. 1, 2 (type locality: East China Sea, 120-122 m); Haig, 1973: 278, Fig. 2a-f; Macpherson and Robainas-Barcia, 2015: 56 (full synonymy).

\section{Material examined}

One male (CL $6.1 \mathrm{~mm}$ ), one ovigerous female (CL $7.5 \mathrm{~mm}), 33^{\circ} 05.8^{\prime} \mathrm{N}, 126^{\circ} 47.2^{\prime} \mathrm{E}$, southern Jeju Island,
Korea, 101 m depth, bottom otter trawl, RV Tamgu 1, 25 Apr. 2004.

\section{Description}

Rostrum (Fig. 1a) about 1.5 times longer than wide, with four lateral teeth. Carapace (Fig. 1a) with several interrupted transverse striae on its anterior half; epigastric and parahepatic spines present; lateral margin with small second anterolateral spine, anterior branchial margin with two spines. Pterygostomian flap unarmed. Antennular peduncle (Fig. 1b) with basal segment bearing three distal spines. Ischium of third maxilliped (Fig. 1c) with one flexor spine on distal margin; merus with two flexor spines; carpus unarmed. First pereopod fingers (Fig. 1d) strongly gapped in male and slightly gapped in female, with large proximal tooth. Second pereopod carpus (Fig. 1e) bearing dorsal row of spines; propodus with six strong flexor corneous spines; dactylus about half length of propodus, biunguiculate, with row of teeth on flexor margin. Epipods absent on all pereopods.

\section{Coloration}

Carapace dull light brown; rostrum light reddish brown; first pereopod light brown, with light reddish brown band; second to fourth pereopods with pale brownish bands (Fig. 11a).

\section{Distribution}

Korea, Japan, East China Sea, South China Sea, Philippines, Indonesia, southwestern and eastern Australia, and Vanuatu; depth 31-222 m (Balss 1913, Miyake and Baba 1964, Haig 1973, Macpherson and Robainas-Barcia 2015).

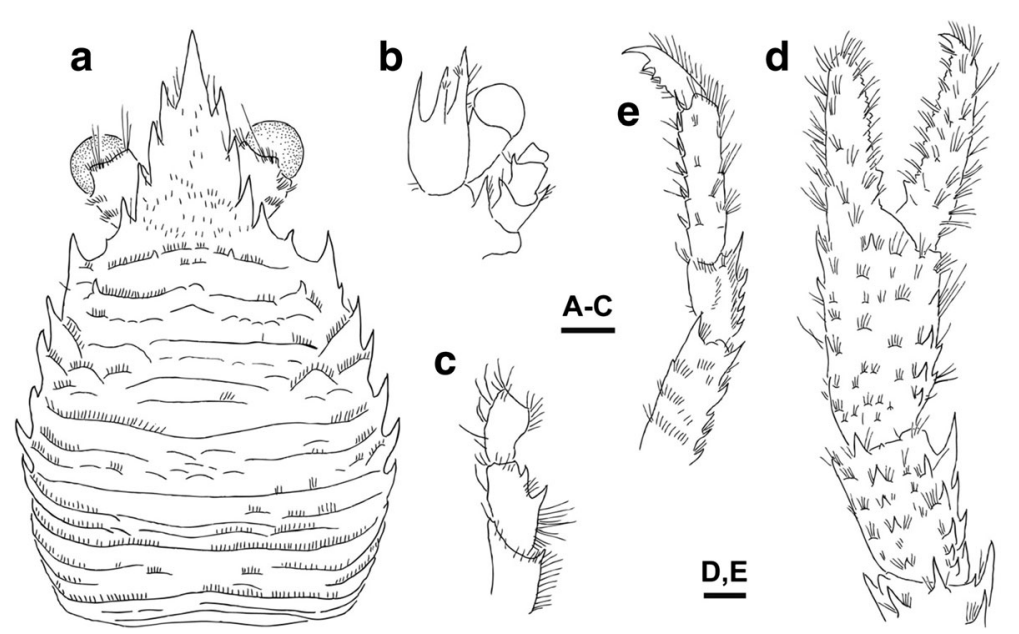

Fig. 1 Galathea balssi Miyake and Baba, 1964. Ovigerous female (CL $7.5 \mathrm{~mm}$ ) from southern Jeju Island. a Carapace and eyes, dorsal. b Left eye, antennular and antennal peduncles, ventral. $\mathbf{c}$ Ischium, merus and carpus of right third maxilliped, lateral. $\mathbf{d}$ Carpus and chela of left first pereopod, dorsal. e Left second pereopod, lateral. Scales $=1.0 \mathrm{~mm}$ 


\section{Remarks}

This species is easily distinguishable from its Korean congeners by the parahepatic spine on the carapace.

\section{Galathea orientalis Stimpson, 1858}

(Korean name: Sae-u-but-i)

(Fig. 2)

Galathea orientalis Stimpson, 1858: 252 (type locality: Lyi-moon passage near Hong Kong, depth $46 \mathrm{~m}$ ); Miers, 1879: 51; Ortmann, 1892: 252, pl. 11, Figs. 10, 10a, 10i; Miyake and Baba, 1967: 232, Fig. 5; Kim, 1973: 175, Text-Fig. 19, pl. 64, Figs, 5a, 5b; Miyake, 1982: 145, with one figure, pl. 49, Fig. 1; Kim and Kim, 1987: 232; Baba et al. 2009: 120, Figs. 100-103; Macpherson and Robainas-Barcia, 2015: 206 (full synonymy).

\section{Material examined}

Two males (CL 3.0, $4.1 \mathrm{~mm}$ ), two ovigerous females (CL 4.4, $5.2 \mathrm{~mm}$ ), Oryuk Islet, Busan, Korea, 0-5 m depth, SCUBA diving, 23 Jul. 2014; six males (CL 2.2-2.9 mm), four females (CL 2.3-3.1 mm), Oryuk Islet, Busan, Korea, 10-15 m depth, SCUBA diving, 3 Dec. 2014; two males (CL 3.0, $3.2 \mathrm{~mm}$ ), one female (CL $3.9 \mathrm{~mm}$ ), Oryuk Islet, Busan, Korea, 0-5 m depth, SCUBA diving, 10 Mar. 2015; one male (CL $2.3 \mathrm{~mm}$ ), two ovigerous females (CL 3.9, 4.0 mm), Oryuk Islet, Busan, Korea, 10-15 m depth, SCUBA diving, 14 Aug. 2015.

\section{Description}

Rostrum (Fig. 2a) about 1.5 times longer than wide, with four lateral teeth. Carapace (Fig. 2a) with lateral orbital angle strongly produced; epigastric spine present; third stria between anteriormost spines on branchial lateral margin interrupted by cervical groove; lateral margin with moderately large second anterolateral spine; anterior branchial margin with two spines. Pterygostomial flap (Fig. 2c) with spine on anterior part. Thoracic sternum (Fig. 2b) about 0.8 times longer than broad; third sternite heart shape, anterior margin medially concave. Second pleomere (Fig. 2a) with two transverse ridges. Antennular peduncle (Fig. 2c) with basal segment bearing three distal spines. Third maxilliped merus (Fig. 2d) bearing two flexor and two extensor spines, carpus with three extensor spines. First pereopod (Fig. 2e) with fingers spooned distally. Epipods present only on first pereopod.

\section{Coloration}

Body light brown; appendages and carapace carinae and spines light reddish brown. However, color substantially varies in this species (see Baba et al. 2009).

\section{Distribution}

Korea, Japan, East China Sea, Hong Kong, Taiwan, and western Australia; shore to $549 \mathrm{~m}$ depth (Stimpson 1858, Miers 1879, Ortmann 1892, Miyake and Baba 1937, Kim 1973, Miyake 1982, Baba et al. 2009, Macpherson and Robainas-Barcia 2015).

\section{Remarks}

G. orientalis is easily distinguished from its Korean congeners by the small spine on the anterior part of the pterygostomian flap. This species is relatively widely distributed in Korea (Kim 1973, Kim and Kim 1987).

\section{Galathea pubescens Stimpson, 1858}

(Korean name: Tel-bo-sae-u-but-i)

(Figs. 3 and 11b)

Galathea pubescens Stimpson, 1858: 90 (type locality: Hakodate and Amami-oshima, Japan, depth 46-60 m); Balss, 1913: 11, Figs. 11, 12; Yokoya, 1933: 57; Makarov, 1938: 88, Fig. 32, 33; Miyake, 1982: 145, pl. 49, Fig. 3;
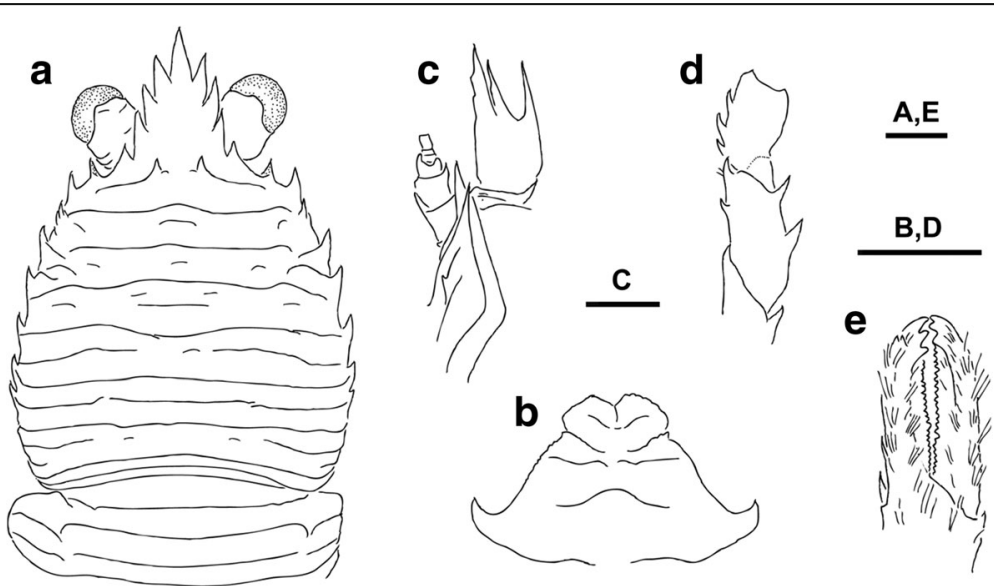

Fig. 2 Galathea orientalis Stimpson, 1858. Ovigerous female (CL $5.2 \mathrm{~mm}$ ) from Oryuk Islet, Busan. a Carapace and eyes, dorsal. b Third and fourth thoracic sternites, ventral. c Right part of cephalothorax, showing antennular and antennal peduncles, ventral. $\mathbf{d}$ Ischium, merus, and carpus of right third maxilliped, lateral. e Distal part of chela of right first pereopod, ventral. Scales $=1.0 \mathrm{~mm}$ 


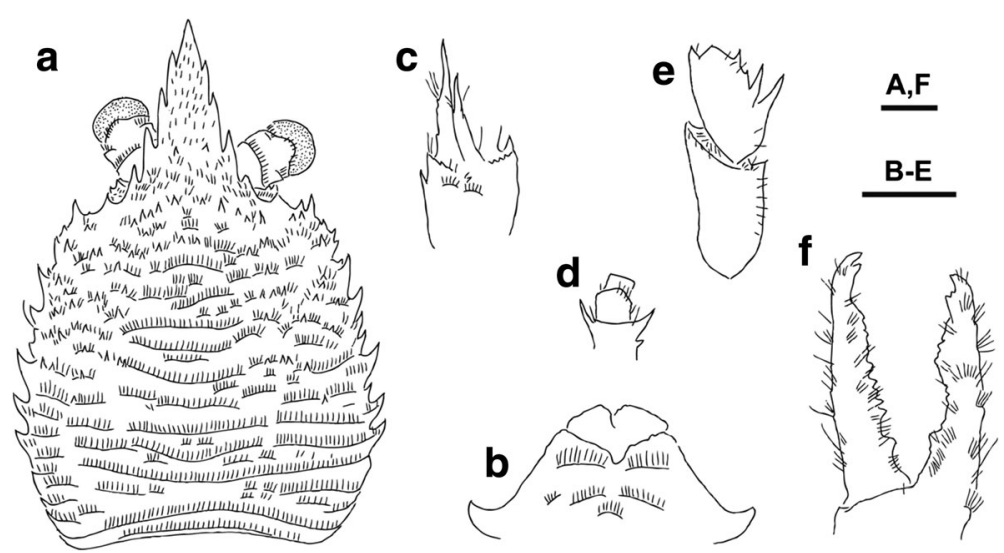

Fig. 3 Galathea pubescens Stimpson, 1858. Male (CL $6.0 \mathrm{~mm}$ ) from eastern Jeju Island. a Carapace and eyes, dorsal. b Third and fourth thoracic sternites, ventral. c Right antennular peduncle, ventral. d Right antennal peduncle, ventral. e Ischium and merus of right third maxilliped, lateral. $\mathbf{f}$ Distal part of chela of left first pereopod, ventral. Scales $=1.0 \mathrm{~mm}$

Baba, 1969: 48, Fig. 5; Kim, 1973: 176, Text-Fig. 20, pl. 65, Figs. 6a, 6b; Kim and Kim, 1987: 233; Baba et al., 2009:125, Figs. 105, 106; Macpherson and RobainasBarcia, 2015: 266, Fig. 120A (full synonymy).

\section{Material examined}

One male (CL $6.0 \mathrm{~mm}$ ), one female (CL $4.2 \mathrm{~mm}$ ), 33 09.6' $\mathrm{N}, 127^{\circ} 28.4^{\prime} \mathrm{E}$, eastern Jeju Island, Korea, $112 \mathrm{~m}$ depth, bottom otter trawl, RV Tamgu 1, 25 Apr. 2004; one ovigerous female (CL $3.9 \mathrm{~mm}$ ), $33^{\circ} 24.8^{\prime} \mathrm{N}, 127^{\circ} 43.5^{\prime} \mathrm{E}$, eastern Jeju Island, Korea, $117 \mathrm{~m}$ depth, bottom otter trawl, RV Tamgu 1, 26 Oct. 2006; one ovigerous female (CL $7.6 \mathrm{~mm}$ ), $32^{\circ} 17.7^{\prime} \mathrm{N}, 126^{\circ} 15.3^{\prime} \mathrm{E}$, southern Jeju Island, Korea, $97 \mathrm{~m}$ depth, bottom otter trawl, RV Tamgu 1, 13 Apr. 2008.

\section{Description}

Rostrum (Fig. 3a) about 1.5 times longer than wide, lateral margin with four teeth. Carapace (Fig. 3a) pubescent dorsally, with many small spines on its anterior half; lateral orbital angle with small spine; epigastric region with row of small spines arranged in concentric arc; lateral margin with three to four small spines between anterolateral spine and anterior most branchial spine; branchial margin with three to four spines in its anterior half. Pterygostomian flap unarmed. Second and third pleomeres with four transverse ridges each. Thoracic sternum (Fig. 3b) about 0.7 times longer than wide; third sternite heart shaped, anterior margin medially excavated. Antennular peduncle (Fig. 3c) with basal segment bearing welldeveloped distodorsal and distolateral spines, distomesial spine minute. First segment of antennal peduncle (Fig. 3d) bearing one distal spine on lateral margin and two mesial spines. Third maxilliped merus (Fig. 3e) with three flexor spines, occasionally one small additional spine between distal and second spines; extensor margin with two distal spines. First pereopod (Fig. 3f) with fingers distally spooned, cutting edge with intermeshing teeth. Epipods only on first pereopod.

\section{Coloration}

Carapace and anterior half of abdomen orange, whitish along midline; first pereopod orange with whitish spine tips (Fig. 11b).

\section{Distribution}

Widely distributed in the Indo-West Pacific: Korea, Japan, Taiwan, East China Sea, South China Sea, Philippines, New Caledonia, Central Queensland, Western Australia, Tanzania, and South Africa; depth 45-494 m (Stimpson 1858, Balss 1913, Yokoya 1933, Makarov 1938, Miyake 1982, Baba 1962, Kim 1987, Baba et al. 2009 Macpherson and Robainas-Barcia 2015).

\section{Remarks}

The present species is easily distinguished from its Korean congeners by the pubescent carapace and the numerous small spines on the anterior part of the carapace.

\section{Galathea rubromaculata Miyake and Baba, 1967}

(New Korean name: Jem-bak-i-sae-u-but-i)

(Fig. 4)

Galathea rubromaculata Miyake and Baba, 1967: 236, Figs. 7, 8 (type locality: East China Sea, $32^{\circ} 24.8^{\prime} \mathrm{N}, 129^{\circ}$ 24.7'E, depth $173 \mathrm{~m}$ ); Baba, 2005: 245; Poore et al., 2011: 333, pl. 11G-H; Macpherson and Robainas-Barcia, 2015: 271 (full synonymy).

\section{Material examined}

One male (CL $3.9 \mathrm{~mm}$ ), 33 $15.4^{\prime} \mathrm{N}, 127^{\circ} 39.8^{\prime} \mathrm{E}$, eastern Jeju Island, Korea, $132 \mathrm{~m}$ depth, bottom otter trawl, RV Tamgu 20, 28 Mar 2013. 


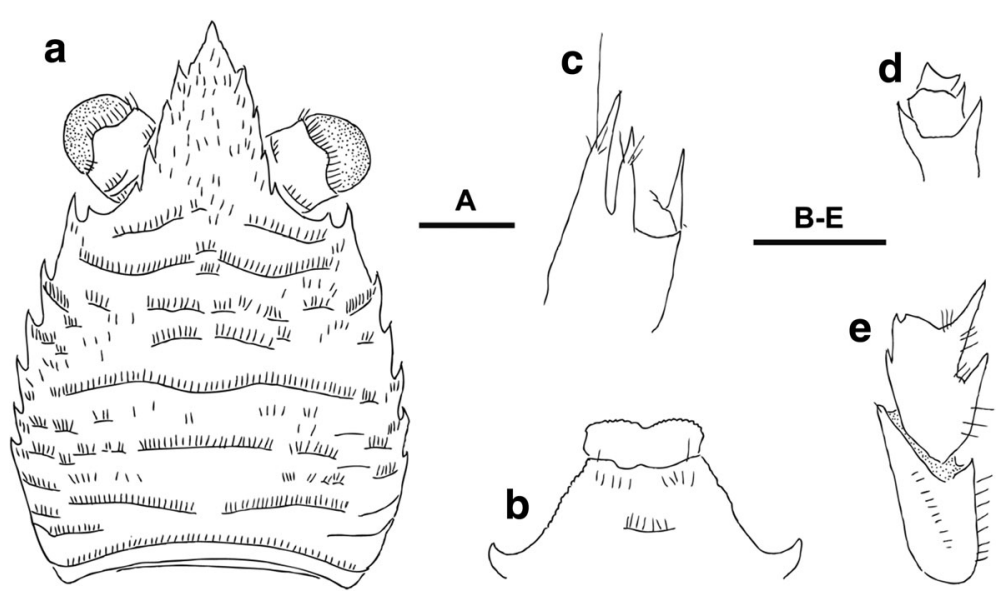

Fig. 4 Galathea rubromaculata Miyake and Baba, 1967. Male (CL $3.9 \mathrm{~mm}$ ) from eastern Jeju Island. a Carapace and eyes, dorsal. b Third and fourth thoracic sternites, ventral. c Right antennular peduncle, ventral. $\mathbf{d}$ Right antennal peduncle, ventral. e Ischium and merus of right third maxilliped, lateral. Scales $=1.0 \mathrm{~mm}$

\section{Description}

Rostrum (Fig. 4a) broadly triangular with four shallowly incised lateral teeth. Carapace (Fig. 4a) weakly striated, without gastric spines; lateral margin without second anterolateral spine; anterior branchial margin with two spines. Pterygostomian flap unarmed. Thoracic sternum (Fig. 4b) about 0.8 times longer than wide; third sternite rectangular, posterior margin nearly straight. Antennular peduncle (Fig. 4c) with basal segment bearing three terminal spines. First segment of antennal peduncle (Fig. 4d) bearing one distal spine on each lateral and mesial margins; second segment with one distal spine on mesial margin. Merus of third maxilliped (Fig. 4e) with two stout ventral and two small dorsal spines. Epipods absent from all pereopods.

\section{Coloration}

Red spots bilaterally arranged on white carapace and pleon.

\section{Distribution}

Korea, Japan, and Philippines; depth 132-500 m (Miyake and Baba 1967, Baba 2005, Poore et al. 2011, Macpherson and Robainas-Barcia 2015).

\section{Remarks}

This species differs from its Korean congeners by having weakly striated carapace and lacking gastric spines. Color of live individuals is also distinctive: red spots on a carapace and pleon.

Family Munididae Ahyong, Baba, Macpherson and Poore, 2010

(New Korean name: Ba-neul-i-ma-sae-u-but-i-gwa)

Genus Bathymunida Balss, 1914

(New Korean Name: Jjalb-eun-ba-neul-i-ma-sae-u-buti-sok)

Bathymunida brevirostris Yokoya, 1933
(New Korean name: Jjalb-eun-ba-neul-i-ma-sae-u-but-i) (Figs. 5 and 11c)

Munida brevirostris Yokoya, 1933: 64, Fig. 28 (type locality: north of Goto Island, Japan, depth $106 \mathrm{~m}$ ).

Bathymunida brevirostris: Baba, 1970: 59, Figs. 1, 2; Baba and de Saint Laurent, 1996: 450, Fig. 8 (full synonymy); Baba, 2005: 239; Baba et al., 2008: 56.

\section{Material examined}

One female (CL $5.1 \mathrm{~mm}$ ), $33^{\circ} 24.8^{\prime} \mathrm{N}, 127^{\circ} 43.5^{\prime} \mathrm{E}$, eastern Jeju Island, Korea, $117 \mathrm{~m}$ depth, bottom otter trawl, RV Tamgu 1, 26 Oct. 2006.

\section{Description}

Rostrum (Fig. 5a) anteriorly narrowed with welldeveloped supraocular spines distinctly exceeding minute median rostral spine. Carapace (Fig. 5b) without continuous ridges; minute scale-like striae on dorsal surface, especially numerous on gastric region; gastric and cardiac processes strongly compressed laterally; postcervical spines pronounced; anterolateral margin with small spine, branchial marginal spines relatively strong. Eyestalks (Fig. 5a) without tubercles; eyelashes barely discernible. Merus and ischium of third maxilliped (Fig. 5b) bearing distal spine on flexor margin. Second pereopod propodus (Fig. 5c) with row of small corneous spines on ventral margin; dactylus slender, slightly shorter than propodus, slightly curved in distal half, flexor margin with one spiniform seta at its midlength, approximately.

\section{Coloration}

Carapace and abdomen pale brown with several scattered orange-red spots; chelipeds pale brown with red 


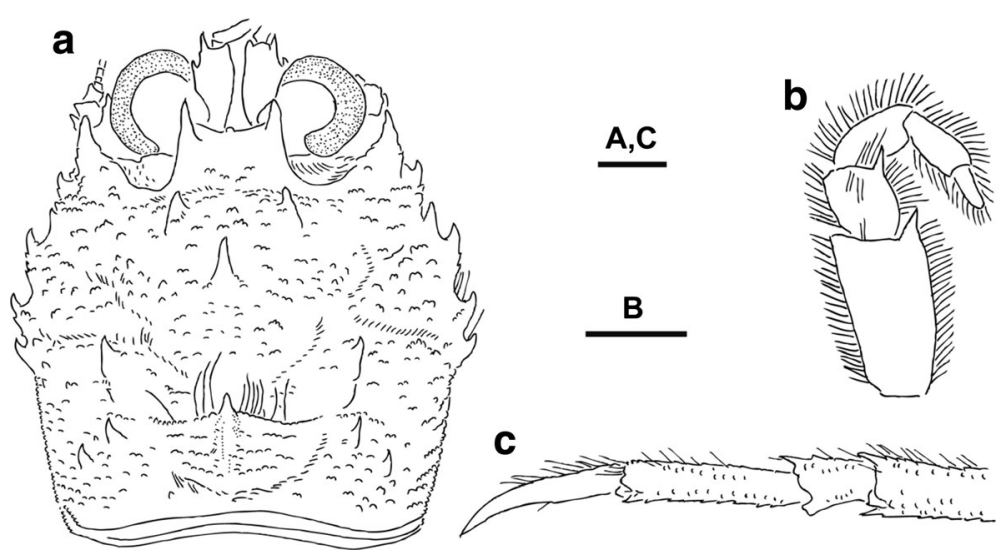

Fig. 5 Bathymunida brevirostris Yokoya, 1933. Ovigerous female (CL $5.1 \mathrm{~mm})$ from eastern Jeju Island. a Carapace and cephalic appendages, dorsal. b Right third maxilliped, lateral. c Merus to dactylus of right second pereopod, lateral. Scales $=1.0 \mathrm{~mm}$

marks on fingers but not on distal and proximal portions (Fig. 11c).

\section{Distribution}

Korea and Japan; depth 105-173 m (Yokoya 1933, Baba 1970, Baba and de Saint Laurent 1996, Baba 2005, Baba et al. 2008).

\section{Remarks}

This species is the sole representative of Bathymunida known in Korean waters and it is restricted to the Korea and Tsushima Straits.

\section{Genus Cervimunida Benedict, 1902}

(New Korean name: Sa-seum-sae-u-but-i-sok)

\section{Cervimunida princeps Benedict, 1902}

(New Korean name: Sa-seum-sae-u-but-i)

(Figs. 6 and 11d)

Cervimunida princeps Benedict, 1902: 249, Fig. 3 [type locality: off Honshu, Japan, "Albatross" St. 3698 (Sagami Bay, Manazuru Zaki), depth 280 m]; Balss, 1913: 18, Fig.
15, pl. 1, Fig. 1; Makarov, 1938: 100, Fig. 37; Miyake, 1982: 149, pl. 50, Fig. 4; Baba, 1986: 167, 288, Fig. 118; Baba et al., 2008: 59, Fig. 3I; Baba et al., 2009: 92, Figs. 75-77 (full synonymy).

\section{Material examined}

One male (CL $30.2 \mathrm{~mm}$ ), southern Geoje Island, Korea, $112 \mathrm{~m}$ depth, bottom otter trawl, TS Kaya (Pukyong National University), 23 Sep. 2002; one male (CL $31.3 \mathrm{~mm}$ ), $33^{\circ} 34.5^{\prime} \mathrm{N}, 125^{\circ} 19.5^{\prime} \mathrm{E}$, southern Gageo Island, Korea, 89 m depth, bottom otter trawl, 9 Nov. 2006; one female (CL $22.9 \mathrm{~mm}$ ), $35^{\circ} 05.3^{\prime} \mathrm{N}, 129^{\circ} 24.1^{\prime} \mathrm{E}$, southern Busan, Korea, $110 \mathrm{~m}$ depth, bottom otter trawl, RV Tamgu 3, 24. Mar. 2004.

\section{Description}

Rostrum (Fig. 6a, b) laterally compressed, strongly arched; dorsal margin with two large and five additional small teeth; ventral margin with one strong tooth; supraocular spines curving dorsally, slightly reaching rostrum midlength. Carapace (Fig. 6a, b) striated; dorsal surface with six epigastric, two parahepatic, two

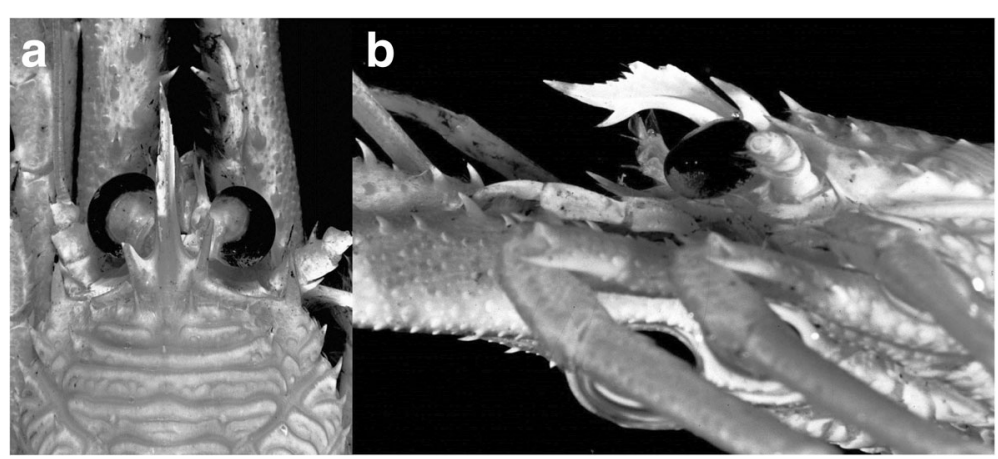

Fig. 6 Cervimunida princeps Benedict, 1902. Male (CL 30.2 mm) from southern Busan. a Carapace, cephalic and thoracic appendages, dorsal. b Same, lateral 
postcervical, and two anterior branchial spines; cervical groove distinct; lateral margin with seven spines including two anterior branchial spines; anterolateral spine well developed. Second to fourth pleomeres with eight spines each on anterior ridge. Epipods absent from all pereopods.

\section{Coloration}

Body coloration orange to orange-red; rostrum deep red at distal and proximal portions and white in between; fingers and mesial margin of chelipeds orange-red (Fig. 11d).

\section{Distribution}

Korea, Japan, East China Sea, Taiwan, and Philippines; depth 76-452 m (Benedict 1902, Balss 1913, Makarov 1938, Miyake 1982, Baba 1986, Baba et al. 2008, Baba et al. 2009).

\section{Remarks}

The genus Cervimunida is represented by two species: C. princeps from the western Pacific and Cervimunida johni Porter, 1903 from the southeastern Pacific.

\section{Genus Munida Leach, 1820}

(Korean name: Ba-neul-i-ma-sae-u-but-i-sok)

\section{Munida caesura Macpherson and Baba, 1993}

(New Korean name: Kkeun-son-ba-neul-i-ma-sae-u-but-i) (Figs. 7 and 11e)

Munida caesura Macpherson and Baba, 1993: 388, Fig. 3 (type locality: Tosa Bay, Japan, depth 250-300 m); Wu et al., 1998: 108, Figs. 20, 21H; Baba et al., 2009: 245, Figs. 27-29 (full synonymy).

\section{Material examined}

Four males (CL 13.1-16.7 mm), one female (CL $12.0 \mathrm{~mm}$ ), $35^{\circ} 05.3^{\prime} \mathrm{N}, 129^{\circ} 24.1^{\prime} \mathrm{E}$, southern Busan, Korea, $110 \mathrm{~m}$ depth, bottom otter trawl, RV Tamgu 3, 24 Mar. 2004.

\section{Description}

Carapace (Fig. 7a) with numerous transverse striae; intestinal region with scale-like stria; frontal margin oblique; anterolateral spines slightly overreaching sinus between rostral and supraocular spines. Pleomeres unarmed. Sternal plastron (Fig. 7b) with numerous striae; third sternite with anterior margin slightly bilobed, posterior margin broader than anterior margin of fourth sternite; fourth and fifth sternites with several oblique striae. Eyes (Fig. 7a) large. Antennular peduncle (Fig. 7c) with basal segment bearing subequal terminal spines. Second segment of antennal peduncle (Fig. 7d) with distomesial spine reaching distal margin of fourth segment and one additional small spine on mesial margin. Merus of third maxilliped (Fig. 7e) bearing one distal extensor spine and two flexor spines. Second pereopod (Fig. 7f) with dactylus proximally stout, proximal flexor margin convex with corneous spines on proximal three quarters and unarmed on distal quarter.

\section{Coloration}

Generally orange red; pereopods with numerous red dots; fingers of chelipeds reddish with whitish tips (Fig. 11f).

\section{Distribution}

Korea, Japan, Taiwan, South China Sea, Philippines, and Indonesia; depth 110-1211 m (Macpherson and Baba 1993, Wu et al. 1998, Baba et al. 2009).

\section{Remarks}

M. caesura can be distinguished from its Korean congeners based on the following characters: (1) second

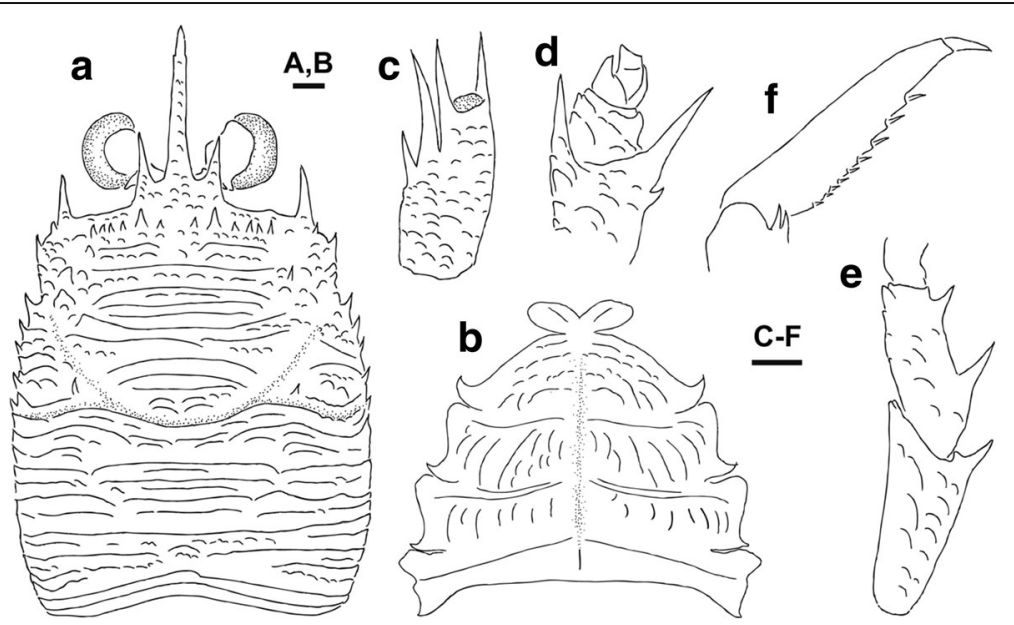

Fig. 7 Munida caesura Macpherson and Baba, 1993. Male (CL 16.7 mm) from southern Busan. a Carapace and eyes, dorsal. b Sternal plastron, ventral. c Right antennular peduncle, ventral. d Right antennal peduncle, ventral. e Ischium and merus of right third maxilliped, lateral. f Dactylus of right second pereopod, lateral. Scales $=1.0 \mathrm{~mm}$ 
pleomere unarmed on anterior ridge; (2) anterior margin of the third thoracic sternite weakly bilobed; and (3) posterior margin of the third thoracic sternite broader than the anterior margin of the fourth sternite.

\section{Munida japonica Stimpson, 1858}

(Korean name: Ba-neul-i-ma-sae-u-but-i)

(Figs. 8 and 11f)

Munida japonica Stimpson, 1858: 252 (type locality: Kagoshima Bay, Japan, depth $36 \mathrm{~m}$; type material extinct); Miyake and Baba, 1967: 240, Figs. 11, 12; Macpherson and Baba, 1993: 399, Fig. 9 [neotype designated (type locality: Makura-zaki, Kagoshima Pref., Japan, depth 145 m)]; Wu et al., 1998: 115, Figs. 24, 26F, G; Komai et al., 2002: 55; Baba et al., 2009: 163, Figs. 142-148 (full synonymy).

?Munida japonica: Kim, 1973: 178, pl. 65, Fig. 7; Miyake, 1982: 146, pl. 49, Fig. 4.

\section{Material examined}

One male (CL $9.1 \mathrm{~mm}$ ), 33 $00.9^{\prime} \mathrm{N}, 125^{\circ} 13.9^{\prime} \mathrm{E}$, western Jeju Island, Korea, $90 \mathrm{~m}$ depth, bottom otter trawl, RV Tamgu 1, 26 Mar 2003; one male (CL 6.9 mm), 3300.0' $\mathrm{N}, 126^{\circ} 08.6^{\prime} \mathrm{E}$, western Jeju Island, Korea, $114 \mathrm{~m}$ depth, bottom otter trawl, 29 Mar. 2003; one female (CL $7.8 \mathrm{~mm}), 33^{\circ} 30.0^{\prime} \mathrm{N}, 127^{\circ} 50.6^{\prime} \mathrm{E}$, northeastern Jeju Island, Korea, $112 \mathrm{~m}$ depth, bottom otter trawl, RV Tamgu 3, 5 Apr. 2003; one female (CL $8.9 \mathrm{~mm}$ ), 33 09.6' $\mathrm{N}$, $127^{\circ} 28.4^{\prime} \mathrm{E}$, eastern Jeju Island, Korea, $112 \mathrm{~m}$ depth, bottom otter trawl, RV Tamgu 1, 25 Apr. 2004; one male (CL $7.6 \mathrm{~mm}$ ), $33^{\circ} 24.8^{\prime} \mathrm{N}, 127^{\circ} 43.5^{\prime} \mathrm{E}$, eastern Jeju Island, Korea, $117 \mathrm{~m}$ depth, bottom otter trawl, RV Tamgu 1, 26 Oct. 2006.

\section{Description}

Carapace (Fig. 8a) with frontal margin slightly oblique; anterior spine not reaching sinus level between rostrum and supraocular spine; posterior branchial margin with five spines; no scale-like or short stria on intestinal region. Second pleomere (Fig. 8a) with two spines on each side of anterior transverse stria. Sternal plastron (Fig. 8b) with few striae on fourth sternite; anterior margin of fourth sternite contiguous to median part of posterior margin of third sternite. Eyes (Fig. 8a) large. Basal segment of antennular peduncle (Fig. 8c) with terminal spines subequal. First segment of antennal peduncle (Fig. 8d) bearing distomesial spine almost reaching distal margin of third segment; second segment bearing small mesial spine and prominent distomesial spine overreaching distal margin of fourth segment. Merus of third maxilliped (Fig. 8e) bearing distinct distal spine on extensor margin; flexor margin with three spines. First pereopod (Fig. 8f) with fingers as long as palm, each bearing proximal spines fairly dorsal, and between subterminal and basal spines. Flexor margin of dactylus in second pereopod (Fig. 8g) bearing corneous spines in proximal two thirds and unarmed on distal portion.

\section{Coloration}

Generally orange red; chelipeds with whitish lateral margins and reddish mesial margins; ambulatory legs with slight reddish brown and white bands (Fig. 11g).

\section{Distribution}

Korea, Japan, East China Sea, Taiwan, Philippines, and Indonesia; depth 22-732 m (Stimpson 1858, Miyake and Baba 1967, Macpherson and Baba 1993, Wu et al. 1998, Komai et al. 2002, Baba et al. 2009).

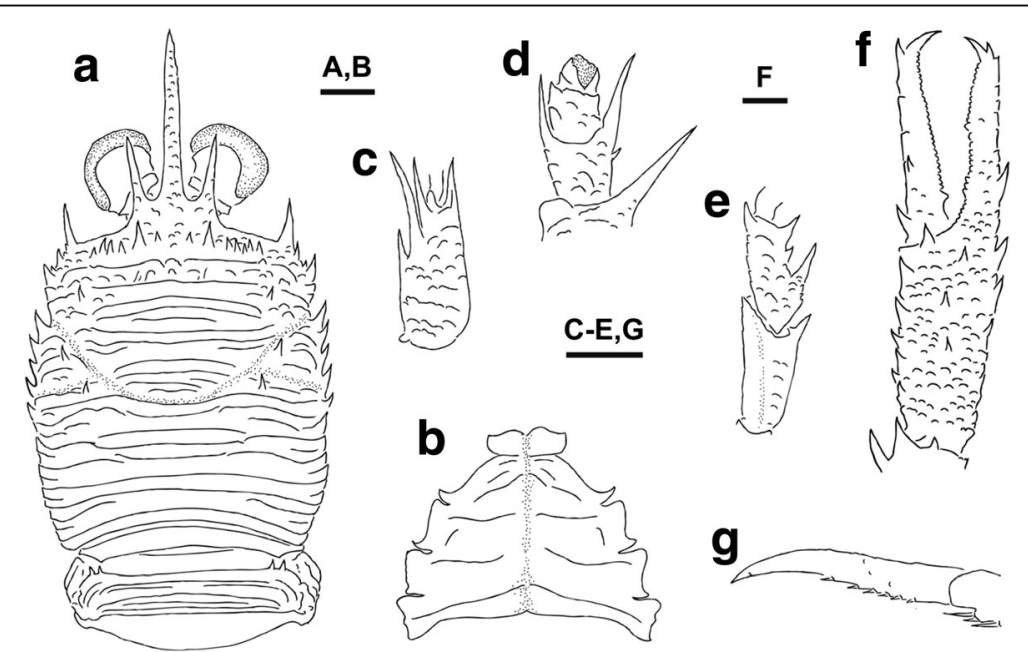

Fig. 8 Munida japonica Stimpson, 1858. Male (CL 6.9 mm) from western Jeju Island. a Carapace and eyes, dorsal. b Sternal plastron, ventral. c Right antennular peduncle, ventral. $\mathbf{d}$ Right antennal peduncle, ventral. e Ischium and merus of right third maxilliped, lateral. $\mathbf{f}$ Chela of right first pereopod, dorsal. g Dactylus of left second pereopod, lateral. Scales $=1.0 \mathrm{~mm}$ 


\section{Remarks}

M. japonica is easily distinguished from its two Korean congeners, as it has two spines on each side of anterior ridge of the second pleomere and few striae on the fourth and fifth thoracic sternites. Macpherson and Baba (1993) clarified the taxonomy of $M$. japonica designating a neotype, as previous records of this species comprised incorrect identifications. Although Kim (1973) recorded M. japonica from Korea, it is difficult to fully assess the identity of the materials used by this author without reexamining them. Thus, Kim's (1973) record is questionably included in the synonymy. Nevertheless, the present study confirms the occurrence of $M$. japonica in Korea. This species is widely distributed in Korean waters from Busan to western Jeju Island.

Munida pherusa Macpherson and Baba, 1993

(New Korean name: Ju-reum-ba-neul-i-ma-sae-u-but-i) (Fig. 9)

Munida pherusa Macpherson and Baba 1993: 408, fig. 15 (type locality: Philippines, $13^{\circ} 56.5^{\prime} \mathrm{N}, 120^{\circ} 20.7^{\prime} \mathrm{E}$, depth $136-$ $152 \mathrm{~m}$ ); Wu et al., 1998: 122, Figs 28, 35B; Komai et al. 2002: 55; Baba et al., 2009: 178, Figs. 158, 159 (full synonymy).

\section{Material examined}

One female (CL $6.9 \mathrm{~mm}$ ), $33^{\circ} 30.0^{\prime} \mathrm{N}, 127^{\circ} 50.6^{\prime} \mathrm{E}$, northeastern Jeju Island, Korea, $112 \mathrm{~m}$ depth, bottom otter trawl, RV Tamgu 3, 5 Apr. 2003; two males (CL 3.0, $8.9 \mathrm{~mm}$ ), 33 $24.8^{\prime} \mathrm{N}, 127^{\circ} 43.5^{\prime} \mathrm{E}$, eastern Jeju Island, Korea, $117 \mathrm{~m}$ depth, bottom otter trawl, RV Tamgu 1, 26 Oct. 2006.

\section{Description}

Carapace (Fig. 9a) with median gastric spine; branchial margin with five spines. Pleomeres unarmed. Sternal plastron (Fig. 9b) with numerous striae; third sternite with anterior margin producing two distinct lobes, posterior margin slightly narrower than anterior margin of fourth sternite. Eyes (Fig. 9a) large. Basal segment of antennular peduncle (Fig. 9c) bearing two subequal spines. First segment of antennal peduncle (Fig. 9d) bearing distomesial spine almost reaching distal margin of third segment; distomesial spine of second segment reaching distal margin of fourth peduncular segment. Merus of third maxilliped (Fig. 9e) with three spines on flexor margin; extensor margin with distal spine. Fingers of first pereopod (Fig. 9f) about two thirds of length of propodus; cutting edges strongly gapped in males, slightly gapped in female, each with proximal spine. Second pereopod (Fig. 9g) with dactylus bearing corneous spines on proximal two thirds of flexor margin and unarmed in distal portion.

\section{Distribution}

Korea, Japan, Taiwan, Philippines, and Indonesia; 73-167 m (Macpherson and Baba 1993, Wu et al. 1998, Komai et al. 2002, Baba et al. 2009).

\section{Remarks}

$M$. pherusa is distinguished from the closely related $M$. caesura by the two distinctly produced lobes in the anterior margin of the third thoracic sternite, and by showing a narrower posterior margin than the anterior margin of the fourth sternite.

\section{Genus Paramunida Baba, 1988}

(New Korean name: Ga-si-sae-u-but-i-sok)

Paramunida scabra Henderson, 1885

(Korean name: Ga-si-sae-u-but-i)

(Figs. 10 and 11)

Munida scabra Henderson, 1885: 409 (type locality: off the Ki (Kei) Island, $05^{\circ} 49^{\prime} 15^{\prime \prime} \mathrm{S}, 132^{\circ} 14^{\prime} 15^{\prime \prime} \mathrm{E}$, depth $236 \mathrm{~m}$ ); Henderson, 1888: 134, pl. 15, Figs. 4, 4a, 4b; Miyake and Baba, 1967: 242, Fig. 13; Kim, 1973: 178;

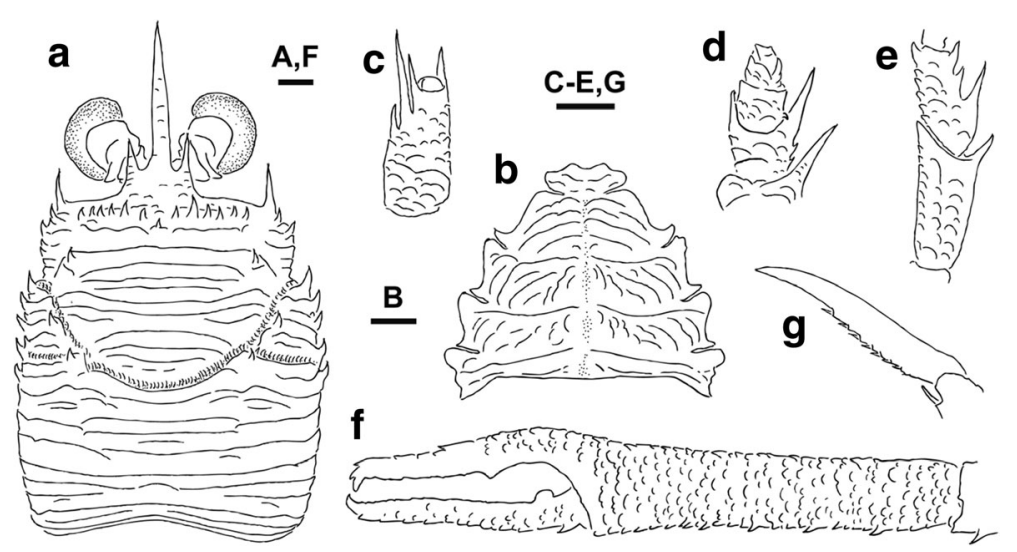

Fig. 9 Munida pherusa Macpherson and Baba, 1993. Male (CL 8.9 mm) from eastern Jeju Island. a Carapace and eyes, dorsal. b Sternal plastron, ventral. c Right antennular peduncle, ventral. d Right antennal peduncle, ventral. e Ischium and merus of right third maxilliped, lateral. f Chela of right first pereopod, dorsal. g Dactylus of left second pereopod, lateral. Scales $=1.0 \mathrm{~mm}$ 


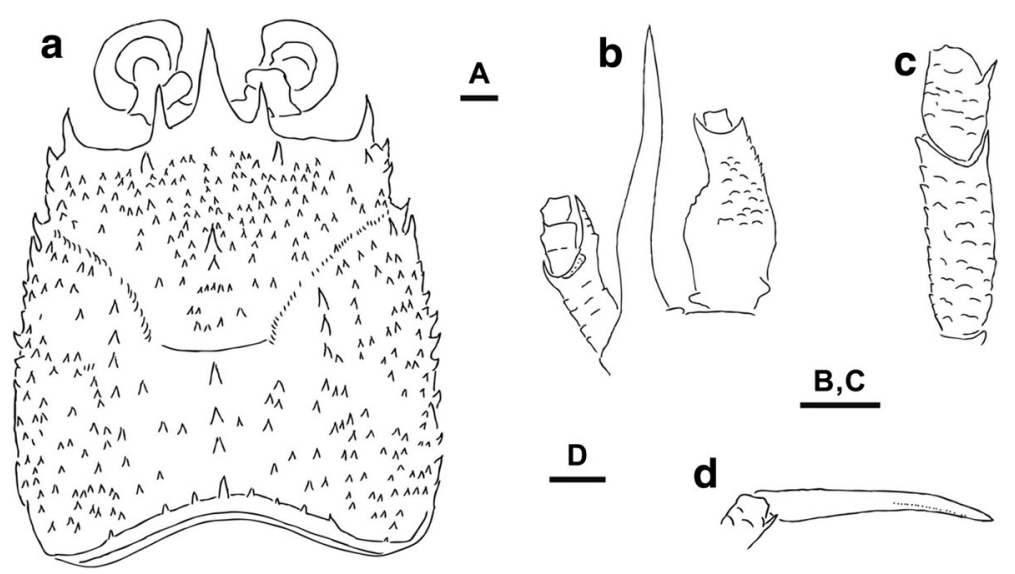

Fig. 10 Paramunida scabra Henderson, 1885. Female $(C L 11.1 \mathrm{~mm})$ from southern Busan. a Carapace and eyes, dorsal. b Right antennular and antennal peduncles, ventral. $\mathbf{c}$ Ischium and merus of right third maxilliped, lateral. $\mathbf{d}$ Dactylus of right second pereopod, lateral. Scales $=1.0 \mathrm{~mm}$

Miyake, 1982: 149, pl. 50, Fig. 2; Baba, 1986: 175, 292, Fig. 125; Kim and Kim, 1987: 233.

Paramunida scabra: Macpherson 1993: 462, Fig. 8; Baba et al., 2009: 281, Figs. 257, 258 (full synonymy).

\section{Material examined}

Two males (CL 11.0, $11.1 \mathrm{~mm}$ ), one female (CL $11.1 \mathrm{~mm}$ ), $34^{\circ} 49.9^{\prime} \mathrm{N}, 129^{\circ} 04.3^{\prime} \mathrm{E}$, southern Busan, Korea, $93 \mathrm{~m}$, bottom otter trawl, RV Tamgu 3, 24 Sep. 2008.

\section{Description}

Rostrum (Fig. 10a) with thin dorsal carina; supraocular spine reaching rostrum midlength. Carapace (Fig. 10a) median gastric region with two spines; cardiac region with row of four spines on midline. Posterior ridge of fourth pleomere with distinct single median spine. Sternal plastron with striae. Antennal peduncle (Fig. 10b) with prolongation of first segment overreaching distal margin of antennular peduncle; second segment with

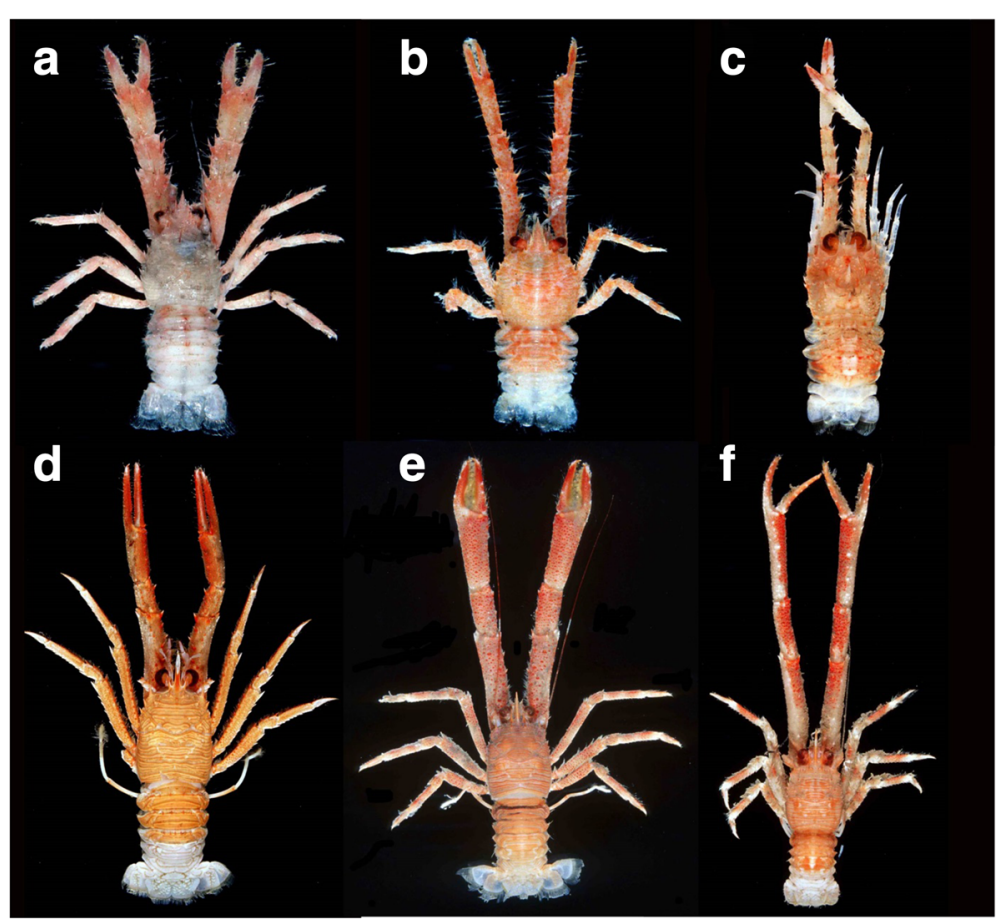

Fig. 11 The six Galatheoidea described in the present study. a Galathea balssi Miyake and Baba, 1964: ovigerous female (CL 7.5 mm) from southern Jeju Island. b Galathea pubescens Stimpson, 1858: male (CL $6.0 \mathrm{~mm})$ from eastern Jeju Island. c Bathymunida brevirostris Yokoya, 1933: ovigerous female (CL $5.1 \mathrm{~mm}$ ) from eastern Jeju Island. d Cervimunida princeps Benedict, 1902: female (CL $22.9 \mathrm{~mm}$ ) from southern Busan. e Munida caesura Macpherson and Baba, 1993: male (CL 16.7 mm) from southern Busan. f Munida japonica Stimpson, 1858: male (CL $6.9 \mathrm{~mm}$ ) from western Jeju Island 
Table 1 Geographic ranges of the galatheoid species inhabiting Korean waters recorded in the present study

\begin{tabular}{|c|c|c|c|c|c|c|c|}
\hline Species & Japan & Taiwan & Philippines & Indonesia & Australia & Indian Ocean & Depth (m) \\
\hline${ }^{\mathrm{a} G a l a t h e a ~ b a l s s i ~}$ & + & & + & + & + & & $31-222$ \\
\hline Galathea orientalis & + & + & & & + & & $0-549$ \\
\hline Galathea pubescens & + & + & + & & + & + & $45-494$ \\
\hline a'Galathea rubromaculata & + & & + & & & & $132-500$ \\
\hline a'Bathymunida brevirostris & + & & & & & & $105-173$ \\
\hline${ }^{a}$ Cervimunida princeps & + & + & + & & & & $76-452$ \\
\hline a'Munida caesura & + & + & + & + & & & 110-1211 \\
\hline Munida japonica & + & + & + & + & & & $22-732$ \\
\hline aMunida pherusa & + & + & + & + & & & 73-167 \\
\hline Paramunida scabra & + & + & + & + & & + & $70-1630$ \\
\hline Total & 10 & 7 & 8 & 5 & 3 & 2 & \\
\hline
\end{tabular}

${ }^{\mathrm{a} N e w l y ~ r e c o r d e d ~ i n ~ K o r e a ~}$

well-developed distomesial spine nearly reaching distal margin of fourth peduncular segment. Merus of third maxilliped (Fig. 10c) bearing one distal spine on flexor margin. Second pereopod (Fig. 10d) with flexor margin of dactylus slightly curved distally, unarmed on flexor margin.

\section{Coloration}

Carapace and abdomen generally light pink or reddish brown; epigastric and cardiac regions reddish; first to fourth pereopods whitish, with red bands and a few small red spots; first pereopod fingers whitish with reddish distal and proximal parts.

\section{Distribution}

Korea, Japan, Taiwan, Hong Kong, Philippines, Indonesia, East and South China Sea, and Eastern Africa; depth 70-1630 m (Henderson 1885, 1888, Miyake and Baba 1967, Kim 1973, Miyake 1982, Baba 1986, Macpherson 1993, Baba et al. 2009).

\section{Remarks}

This species is the sole representative of the genus Paramunida known from Korean waters.

\section{Conclusions \\ Biogeography}

The geographic ranges of the 10 Galatheoidea species recorded from Korean waters are summarized in Table 1. Although all species are commonly found in Japanese waters, six species were recorded for the first time in Korean waters. Seven species are also found in Taiwan, eight in the Philippines, five in Indonesia, and three in Australia. Two species, G. pubescens and $P$. scabra are widely distributed in the Indo-West Pacific. $B$. brevirostris is endemic to Korea and Tsushima Straits.
Key to the Galatheoidea found in Korean waters

1. Rostrum broad, flattened, and subtriangular; supraocular spines present or absent

Galatheidae, Galathea 2

- Rostrum slender and spiniform; supraocular spines always present . Munididae 5

2. Carapace with parahepatic spine G. balssi

- Carapace without parahepatic spine ... 3

3. Epipod absent on first pereopod G. rubromaculata

- Epipod present on first pereopod 4

4. Pterygostomian flap with spine on anterior part G. orientalis

- Pterygostomian flap without spine on surface ...................................................... G. pubescens 5. Rostrum with dorsal and ventral spines . Cervimunida princeps

- Rostrum without dorsal and ventral spines 6

6. Rostrum spiniform, well developed; carapace with distinct transverse ridges or striae Munida 8

- Rostrum short; carapace without distinct transverse ridges or striae 7

7. Carapace with prominent gastric and cardiac spines; first segment of antennal peduncle with short process . Bathymunida brevirostris

- Carapace covered with granules or spinules, lacking prominent gastric and cardiac spines; first segment of antennal peduncle with elongate, anteriorly directed process Paramunida scabra 8. Second pleomere with two spines on each side of anterior ridge M. japonica

- Second pleomere unarmed on anterior ridge 9. Third thoracic sternite with anterior margin slightly bilobed, posterior margin broader than anterior margin of fourth sternite M. caesura 
- Third thoracic sternite with anterior margin producing two distinct lobes, posterior margin narrower than anterior margin of fourth sternite

M. pherusa

\section{Acknowledgements}

This work was supported a grant by the National Institute of Fisheries Science, Korea (R2016032).

\section{Authors' contributions}

JNK and JHC carried out the sampling and identification each species. JNK and MHK participated in drafted the manuscript. YJI conceived of the study and participated in its design and coordination. All authors read and approved the final manuscript.

\section{Competing interests}

The authors declare that they have no competing interests.

\section{Author details}

'West Sea Fisheries Research Institute, National Institute of Fisheries Science, Incheon 22383, South Korea. ${ }^{2}$ Korea Inter-University Institute of Ocean Science, Pukyong National University, Busan 48513, South Korea. ${ }^{3}$ Southeast Fisheries Research Institute, National Institute of Fisheries Science, Tongyeong 53085, South Korea.

\section{Received: 4 October 2016 Accepted: 7 October 2016}

\section{Published online: 26 October 2016}

\section{References}

Ahyong ST, Baba K, Macpherson E, Poore GCB. A new classification of the Galatheoidea (Crustacea: Decapoda: Anomura). Zootaxa. 2010;2676:57-68.

Baba K. Chirostylids and galatheids from dredgings and trawlings operated in the East China Sea by the Japanese Fisheries Research Vessel Kaiyo Maru in 1967. OHMU. 1969;2:41-57.

Baba K. Redescription of Bathymunida brevirostris (Yokoya, 1933) (Crustacea, Decapoda, Galatheidae). Mem Fac Educ, Kumamoto Univ, Sect 1 (Nat Sci). 1970;18:59-62

Baba K. Reptantia Macrura, Anomura and Brachyura. In: Baba K, Hayashi K, Toriyama M, editors. Japan Fisheries Resource Conservation Association, Decapod Crustaceans from continental shelf and slope around Japan. Tokyo: Japan Fisheries Resource Conservation Association; 1986. p. 148-231. 279-316.

Baba K. Deep-sea chirostylid and galatheid crustaceans (Decapoda: Anomura) from the Indo-West Pacific, with a list of species. Galathea Rep. 2005;20:1-317.

Baba K, de Saint Laurent M. Crustacea Decapoda: Revision of the genus Bathymunida Balss, 1914, and description of six new related genera (Galatheidae). In: Résultats des Campagnes MUSORSTOM, vol. 15. Crosnier A. ed. Mém Mus Natl Hist Nat Paris. 1996;168:433-502.

Baba K, Macpherson E, Poore GCB, Ahyong ST, Bermudez A, Cabezas A, Lin CW, Nizinski M, Rodrigues C, Schnabel KE. Catalogue of squat lobsters of the world (Crustacea: Decapoda: Anomura-families Chirostylidae, Galatheidae and Kiwaidae). Zootaxa. 2008;1905:1-220.

Baba K, Macpherson E, Lin CW, Chan TY. Crustacean Fauna of Taiwan. Squat Lobsters (Chirostylidae and Galatheidae). Keelung, PRC: National Taiwan Ocean University; 2009.

Balss H. Ostasiatische Decapoden. I. Die Galatheidae und Paguridae, in Beiträge zur Naturgeschichte Ostasiens, herausgegeben von Pr. F. Doflein. Abhand. K. Bayerischen Akad Wiss Math Physik Klasse. 1913:Suppl 2:1-85.

Benedict JE. Description of a new genus and forty six new species of crustaceans of the family Galatheidae with a list of the known marine species. Proc Biol Soc Wash. 1902;26:243-334

Haig J. Galatheidae (Crustacea, Decapoda, Anomura) collected by the F.I.S. Endeavour. Rec Aust Mus. 1973:28:269-89.

Henderson JR. Diagnoses of new species of Galatheidae collected during the "Challenger" expedition. Ann Mag Nat Hist. 1885;16:407-21.

Henderson JR. Report on the Anomura collected by H.M.S. Challenger during the years 1873-76. Report on the Scientific Results of the Voyage of H.M.S Challenger during the years 1873-76. Zoology. 1888;27:1-221.

Kim HS. Anomura and Brachyura. Illustrated Encyclopedia of Fauna and Flora of Korea, Vol, 14. Seoul, KR: Ministry of Education; 1973.
Kim HS, Kim CB. The anomuran crabs (including thalassinideans) of Cheju Island and its adjacent waters, Korea (Crustacea: Decapoda). Korean J Syst Zool. 1987;3:225-36

Kim HS, Kim W. Order Decapoda. In: List of Animals in Korea (excluding insects), The Korean Society of Systematic Zoology, ed. Seoul, KR: Academy Publishing Co.; 1997. p. 212-23.

Komai T, Ohtsuka S, Nakaguchi K, Go A. Decapod crustaceans collected from the southern part of the Sea of Japan in 2000-2001 using TRV Toyoshio-maru. Nat Hist Res. 2002:7:19-73.

Macpherson E. Crustacea Decapoda: species of the genus Paramunida Baba, 1988 (Galatheidae) from the Philippines, Indonesia and New Caledonia. In: Résultats des Campagnes MUSORSTOM, vol. 10. Crosnier A. ed. Mém Mus Nat'l Hist Nat, Paris. 1993;156:443-73.

Macpherson E, Baba K. Crustacea Decapoda: Munida japonica Stimpson, 1858 and related species (Galatheidae). In: Résultats des Campagnes MUSORSTOM vol. 10. Crosnier A. ed. Mém Mus Natl Hist Nat Paris. 1993;156:381-420.

Macpherson E, Robainas-Barcia A. Species of the genus Galathea Fabricius, 1793 (Crustacea, Decapoda, Galatheidae) from the Indian and Pacific Oceans, with descriptions of 92 new species. Zootaxa. 2015;3913:1-335.

Makarov W. [Crustacés Décapodes anomures] In: Fauna SSSR (n. ser.), Shtakelberg AA. ed. Akademii Nauk SSSR, Moscow and Leningrad, RU, 1938;16: 1-324.

Miers EJ. On a collection of Crustacea made by Capt. H.C. Dt. John RN, in the Corean and Japanese Seas. Part 1, Podophthalmia. With an appendix by Capt. St. John HC. Proc Zool Soc London. 1879;1879:18-61.

Miyake S. Japanese Crustacean Decapods and Stomatopods in Color, vol. I. Macrura. Hoikusha, Oksaka, JP: Anomura and Stomatopoda; 1982.

Miyake S, Baba K. Two new species of Galathea from Japan and the East China Sea. J Fac Agr Kyushu Univ. 1964;13:205-11.

Miyake S, Baba K. Galatheids of the East China Sea (Chirostylidae and Galatheidae, Decapoda, Crustacea). J Fac Agr Kyushu Univ. 1967;14:225-46.

Ortmann A. Die Decapoden-Krebse des Strassburger Museums, mit besonderer Berücksichtigung der von Herrn Dr. Döderlein bei Japan und bei den Liu-KiuInseln gesammelten und z. Z. im Strassburger Museum aufbewahrten Formen. IV. Die Abtheilungen Galatheidea und Paguridea. Zool Jahr Abth Syst Geogr Biol Theire. 1892;65:241-326.

Poore G, Ahyong ST, Taylor J. In: Poore G, Ahyong ST, Taylor J, editors. The Biology of Squat Lobsters. 2011. CSIRO Publishing, Melbourne, AU and CRC Press, Boca Raton, CA, US

Stimpson W. Prodromus descrioptionis animalium evertebratorum, quae in expeditione ad oceanum Pacificum septentrionalem, a Republica Federate missa, Cadwaldaro Ringgold et Johanne Roders ducibus, obseravit et descripsit. VII. [Preprint (December 1858)]. Proc Acad Nat Sci Philadelphia. 1858;1858:225-52.

World Register of Marine Species (2015) Galatheoidea. World Register of Marine Species Accessed 11 Oct 2015. http://marinespecies.org/aphia.php?p= taxdetails\&id $=106685$.

Wu MF, Chan TY, Yu HP. On the Chirostylidae and Galatheidae (Crustacea: Decapoda: Galatheidea) of Taiwan. Ann Taiwan Mus. 1998:40:75-153.

Yokoya Y. Macrura of Mutsu Bay. Report on the Biological Survey of Mutsu Bay, 16. Sci Rep Tohoku Imp Univ Sendai. 1930;5:525-48.

Submit your next manuscript to BioMed Central and we will help you at every step:

- We accept pre-submission inquiries

- Our selector tool helps you to find the most relevant journal

- We provide round the clock customer support

- Convenient online submission

- Thorough peer review

- Inclusion in PubMed and all major indexing services

- Maximum visibility for your research

Submit your manuscript at www.biomedcentral.com/submit
Biomed Central 